\title{
KAJIAN BENTUK DAN MAKNA KERIS CANTHANG BALUNG DALAM UPACARA GREBEG MULUD DI KERATON KASUNANAN SURAKARTA
}

\author{
Jauhari \\ Sekolah Vokasi, Universitas Negeri Sebelas Maret \\ jauhari@staff.uns.ac.id
}

\begin{abstract}
This research discussed the form and meaning of the Canthang Balung kris in the Grebeg Mulud ceremony at the Kasunanan Palace in Surakarta. The method of this research was a descriptive qualitative research. The datum were obtainned through interviews with primary informants from the Surakarta Palace, written sources in the form of reference books, photos, and videos. In order to obtain the expected data, researcher used data collection techniques through observation, indepth interviews, library research and documentation. The process of data analysis was completed into several steps, those are data collection, data analysis, data display and conclusions. From the results of the study it was concluded that the existence of the Canthang Balung kris was not only used to be a prerequisite instrument in the Grebeg Mulud ceremony at the Kasunanan Palace in Surakarta but also as a cultural product in which had full of symbolic meaning and a mystical, sacred, and beautiful values derived from traditional roots based on Javanese religion, cosmology and mythology. Canthang Balung kris contained the teachings / philosopy of ethics and beauty in the form of visual appearance and life symbols which can lead humans to perfection and the real identity. The form on the Canthang Balung kris became a media for the expression of religious and aesthetics. It was to communicate noble teachings so that they could be understood and grasped by their supporting communities. The symbolic meaning can be interpreted as follows: safety, peace, harmony and fertility.
\end{abstract}

Keywords: Kris, Canthang Balung, shape and meaning

\begin{abstract}
ABSTRAK
Penelitian ini membahas tentang bentuk dan makna keris Canthang Balung dalam upacara Grebeg Mulud di Keraton Kasunanan Surakarta. Metode penelitian ini adalah penelitian kualitatif yang bersifat deskriptif. Data-data diperoleh melalui wawancara dengan narasumber primer dari Keraton Surakarta, sumber tertulis berupa buku referensi, foto dan video. Untuk memperoleh data yang diinginkan, peneliti menggunakan teknik pengumpulan data melalui observasi, wawancara mendalam, studi pustaka dan pendokumentasian. Proses analisis data melalui beberapa tahapan, yaitu pengumpulan data, analisis data, sajian data serta kesimpulan. Dari hasil penelitian diperoleh kesimpulan bahwa keberadaan keris Canthang Balung selain sebagai kelengkapan dalam upacara Grebeg Mulud di Keraton Kasunanan Surakarta juga merupakan produk budaya yang di dalamnya sarat dengan makna simbolis serta memiliki muatan nilai yang bersifat mistis atau sakral, spiritual dan indah bersumber dari akar tradisi yang berpijak pada religi, kosmologi dan mitologi Jawa. Dalam keris Canthang Balung juga termuat ajaran etika dan keindahan berupa penampilan visual dan simbol pandangan hidup yang dapat menuntun manusia menuju kesempurnaan dan jati diri yang sejati. Bentuk pada keris Canthang Balung menjadi wadah pengungkapan ekspresi yang bersifat religius dan estetis, yakni sebagai sarana untuk mengkomunikasikan ajaran-ajaran luhur sehingga dapat dipahami dan ditangkap maksudnya oleh masyarakat pendukungnya. Makna simbolis tersebut dapat ditafsirkan antara lain sebagai berikut: keselamatan, ketentraman, keharmonisan, dan kesuburan.
\end{abstract}

Kata Kunci: Keris, Canthang Balung, bentuk dan makna 


\section{PENDAHULUAN}

\section{A. Latar Belakang}

Keris adalah salah satu artefak peninggalan budaya karya nenek moyang Bangsa Indonesia. Keris mulai dikenal di Indonesia sekitar abad ke-9. Hal ini bisa dilihat dalam Prasasti Karang Tengah dan Prasasti Poh. Dalam prasasti tersebut tertulis kata kres yang artinya "keris". Bukti sejarah mengenai keris juga bisa dilihat dalam Prasasti Rukam yang berangka tahun 829 Saka (907 M) yang menyebutkan:

“...wsi-wsi prakara, wadung, rimwas, patuk-patuk, lukai, tampilan, linggis, tatah, wangkiul, kris, gulumi, kurumbahgi, pamajba, kampi, dom..." ( ...segala macam keperluan yang terbuat dari besi berupa kapak perimbas, beliung, sabit, tampilan, linggis, tatah, bajak, keris, tombak, pisau, ketam, kampit, jarum.."). (Haryono Haryoguritno, 2005 : 12).

Pada awalnya keris merupakan senjata tajam sebagaimana tombak, pedang, wedhung, badik, rencong, patrem, dan cundrik. Pembuatan keris menggunakan teknik tempa yang rumit. Kerumitannya terletak pada seni tempa pamor yang indah dan oleh sebagian orang dianggap mempunyai kekuatan magis, sehingga sampai saat ini keris masih dikeramatkan. Keris disebut juga tosan aji atau wesi aji, artinya besi yang bernilai atau dimuliakan. Dalam beberapa buku disebutkan berbagai pengertian mengenai keris, di antaranya seperti yang dikemukakan oleh Ki Hudoyo Doyodipuro dalam bukunya yang berjudul Keris, Daya Magic, Manfaat, Tuah, Misteri. Keris tidak sekedar karya cipta seni saja, tetapi mempunyai getar-getar daya magis yang memancar dari bilahnya, baik pamor, ricikan, maupun dari urat besinya.

Dari definisi di atas dapat ditarik kesimpulan bahwa keris adalah senjata tajam yang sesuai dengan bentuknya dapat dipergunakan sebagai senjata untuk menusuk atau menikam. Keris merupakan senjata asli budaya Indonesia yang mempunyai nilai keindahan serta wujud dari pencapaian-pencapaian hasil kebudayaan nenek moyang Bangsa Indonesia.

Dalam kosmologi kehidupan masyarakat Jawa, keris merupakan bagian yang tidak terpisahkan dengan konteks dunia yang meliputi alam makrokosmos, mikrokosmos, dan metakosmos. Setiap elemen dalam keris mempunyai makna yang erat kaitannya dengan pandangan hidup masyarakat Jawa. Selain itu, pada masyarakat Jawa muncul anggapan bahwa kesempurnaan seorang manusia (laki-laki) jika sudah memiliki lima unsur simbol yaitu, curiga (senjata), turangga (kendaraan), wisma (tempat tinggal), wanita (pendamping), dan kukila (klangenan). Curiga (senjata) bisa diwujudkan 
dalam bentuk kepemilikan keris yang melambangkan keberanian, keperkasaan, dan kejantanan.

Salah satu keris yang menarik untuk dikaji lebih lanjut adalah keris Canthang Balung yang digunakan oleh abdi dalem Canthang Balung dalam penyelenggaraan upacara Grebeg Mulud di Keraton Kasunanan Surakarta. Secara etimologi, Canthang Balung berasal dari dua kata yaitu, 'canthang' yang berarti sakit dan 'balung' berarti tulang.

Canthang Balung merupakan abdi dalem priya tanpa tuna, yakni memiliki penampilan yang berbeda dengan para abdi dalem lainnya serta perilakunya senantiasa memancing tawa para penontonnya. Abdi dalem ini menggunakan keris dengan warangka bermotif sungging poleng. Dalam setiap kali penampilannya, abdi dalem Canthang Balung selalu membawa kepyak dari tulang yang diselipkan pada jari-jari dan dibunyikan 'crek, crek, crek'. Abdi dalem Canthang Balung merupakan sosok abdi dalem kalonthangan yang mengepalai para pesinden keraton. Abdi dalem ini mempunyai kekhususan tersendiri, ia diperlukan oleh raja, keluarga raja, dan keraton hanya pada saat upacara Grebeg Mulud.

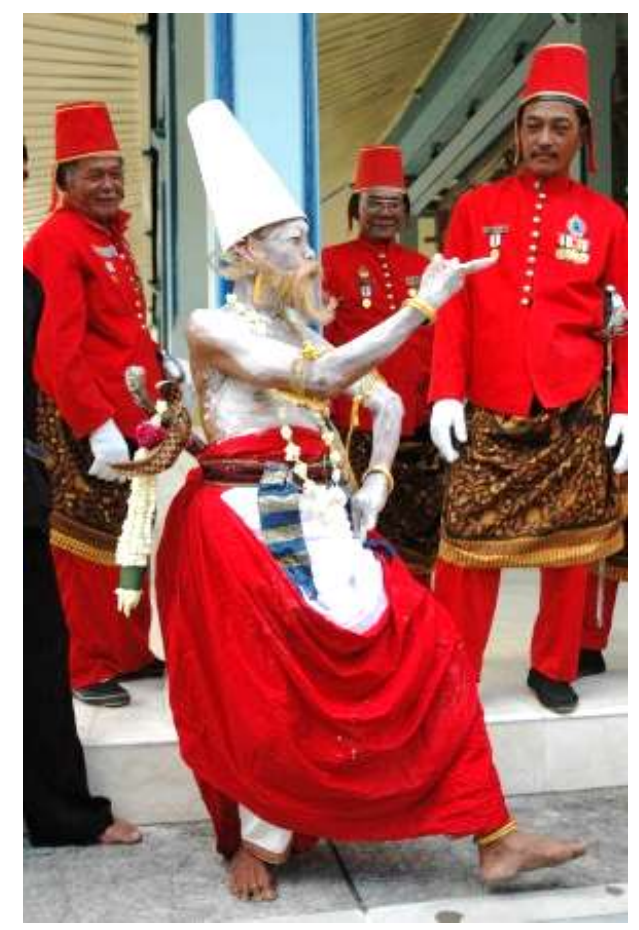

Gambar 1. Abdi dalem Canthang Balung dengan segala atribut yang menyertainnya, memiliki nilai-nilai simbolis dalam budaya Jawa di Keraton Kasunanan Surakarta.

(Foto: Jauhari, 2007). 
Upacara Grebeg Mulud merupakan puncak dari acara sekaten. Secara umum lebih dikenal dengan sebutan gunungan, karena sejumlah makanan disajikan dalam bentuk gunung (tumpeng). Gunungan merupakan alat komunikasi dalam hubungannya dengan sang khalik (Tuhan) sebagai wujud selamatan oleh Sinuwun Paku Buwana, di samping pula bertujuan memperingati hari lahir Nabi Muhammad, yakni setelah tujuh hari berlangsungnya sekaten.

Prosesi acara Grebeg Mulud ini dimulai dengan membawa gunungan dari dalam keraton menuju Masjid Agung. Prosesi gunungan dari keraton menuju Masjid Agung dipimpin patih dengan diiringi pembesar keraton. Di bagian depan pada prosesi ini ditampilkan tarian unik yang diperankan oleh Canthang Balung. Canthang Balung dalam prosesi Grebeg Mulud mengenakan berbagai atribut busana yang unik serta gerakgeriknya yang lucu dan cenderung bebas. Pakaian yang dikenakan adalah dodot bermotif tumbal, serta lainnya bermotif sindur, mengenakan kampuh, mengenakan sumping melati dan membawa tombak serta mengenakan kuluk kepala layaknya kaum brahmana.

Simbol dalam keris tidaklah sekadar mengandung makna, namun juga termuat ajaran etika dan keindahan yang tercitra dalam penampilan bentuknya, dan dapat menjadi perangsang bagi pemakainya untuk bersikap sesuai dengan makna simbol tersebut. Penggunaan simbol dalam keris merupakan sebuah manifestasi sekaligus sebagai sarana atau media untuk menitipkan pesan-pesan ataupun petuah bagi suku bangsanya. Penggunaan simbol-simbol dalam mengungkapkan rasa budayanya, khususnya dalam kosmogoni masyarakat Jawa, tercermin pada semua bidang kehidupannya, baik dalam bahasa sehari-hari, sastra, kesenian, tindakan-tindakan, maupun dalam upacara-upacaranya. Hal ini sangat menarik perhatian karena ternyata dilaksanakan dengan penuh kesadaran, pemahaman dan penghayatan yang tinggi dan dianut secara tradisional dari generasi ke generasi berikutnya. (Herusatoto, 1984: 1).

Pemahaman keris dan makna simbolis dalam bentuk visualisasi keris canthang balung pada upacara Grebeg Mulud, merupakan pemahaman arti sebagian unsur budaya daerah dan unsur kebudayaan nasional yang merupakan bagian dari cultural universal (Condronegoro, 1995: 1).

Juga merupakan suatu proses budaya yang sangat penting untuk dipelajari dan dimengerti oleh para generasi muda dan masyarakat luas, karena kebudayaan merupakan suatu proses belajar yang besar. (Peursen, 1988: 144). 
Hal ini menarik perhatian bagi penulis untuk mencari jawab, agar segala tujuan, dan makna ungkapan-ungkapan simbolis orang Jawa itu terungkapkan. Penelitian ini diharapkan dapat memberikan suatu gambaran yang lebih terfokus tentang kajian makna simbolis keris canthang balung dalam upacara Grebeg Mulud di Keraton Kasunanan Surakarta, mengingat belum terdapat tulisan yang mengkaji mengenai simbolisme keris canthang balung dalam upacara Grebeg Mulud di Keraton Kasunanan Surakarta. Penelitian yang dilakukan penulis akan melihat pada sisi makna simbolis keris pada canthang balung, baik wujud maupun kandungan makna yang tersirat di dalamnya, khususnya dalam eksistensinya pada upacara Grebeg Mulud.

Terkait dengan makna simbolis, pembahasannya akan lebih ditekankan pada makna yang terkandung dalam keris canthang balung seperti warangka keris, hulu keris, bilah keris, dan ubarampe yang digunakan, serta peranan canthang balung dalam upacara Grebeg Mulud di Keraton Kasunanan Surakarta. Untuk menganalisis, penulis menggunakan landasan pemikiran yang dikemukakan oleh Suzzane K. Langer, bahwasannya simbol tidak mewakili objeknya, melainkan merupakan wahana tentang objek. Maksudnya, dalam bicara mengenai sesuatu, berarti kita berbicara tentang konsep mengenai sesuatu itu, dan bukan sesuatu itu sendiri, dan semuanya ini merujuk pada konsep, bukanlah pada sesuatu itu.

Simbol-simbol menurut Jakob Soemardja merupakan penyederhanaan dari aspek-aspek dalam kebudayaan yang dipakai sebagai penghubung untuk menguraikan atau melukiskan segala sesuatu sehingga merupakan hal yang harus diartikan. Bilamana simbol diungkapkan, maka munculah makna. (Sumardja, 2006: 43)

Lebih jauh Langer membedakan antara simbol diskursif dan simbol presentasional. Simbol diskursif lebih cenderung digunakan dalam bahasa tulis ataupun lisan untuk keperluan komunikasi dengan pihak lain (berupa penjelasan), sedangkan simbol presentatif cenderung merupakan bahasa presentasi suatu makna yang tidak bisa dikatakan ke dalam simbol diskursif (berupa penggambaran). Dalam hal ini penulis lebih menekankan pada simbol presentatif oleh karena keberadaan canthang balung dengan segala atributnya merupakan bentuk yang kompleks. Kecuali itu, penulis juga menggunakan landasan pemikiran yang dikemukakan oleh Dillistone. Dalam hal ini, Dillistone memandang bahwa simbol bukanlah sekadar konsep, melainkan sesuatu yang transenden, sesuatu yang lebih besar, sesuatu yang tertinggi, sesuatu yang absolut, konsep, makna, nilai, kepercayaan, realitas, idea dan sebagainnya. Simbol dalam hal ini dimaksudkan sebagai sebuah tanda kehadiran yang bersifat transenden. Acuan simbol tidaklah sekadar konotasi gagasan (rasio) beserta pengalaman manusia 
(rasa), namun juga hadirnya daya-daya (kekuatan) atau energi adikodrati. Simbol diartikan sebagai tanda kehadiran dari 'yang absolut' tersebut. (Sumarja, 2006: 45).

Namun, dalam kajian ini tidak berarti bahwa representasi simbol itu tidak mengacu pada gagasan rasionalnya. Pandangan lain yang juga masih berkaitan dengan simbol dikemukakan oleh V.Turner yang menyatakan bahwa simbol merupakan penyederhanaan dari aspek-aspek dalam kebudayaan yang dipakai sebagai penghubung untuk menguraikan atau melukiskan sesuatu. (Ratna, 2007:176).

Lebih jauh pandangan lain tentang simbol, L.A. White memandang bahwa simbol adalah sebagai pengantar terhadap pemahaman obyek-obyek dan simbol merupakan fenomena fisik yang mempunyai arti bagi yang menggunakannya. (Ratna, 2007: 176).

Pemahaman terhadap simbol dalam kebudayaan Jawa, khususnya yang berkembang di Keraton Kasunanan Surakarta memerlukan penyelaman yang mendalam. Oleh karena di dalamnya terdapat simbol-simbol spiritual. Simbol-simbol tersebut perlu kiranya ditafsirkan sejalan pula dengan keadaan masa kini, untuk memperoleh makna yang lebih komprehensif.

\section{HASIL DAN PEMBAHASAN}

\section{A. Bentuk Keris Canthang Balung}

Keris Canthang Balung sebagaimana yang digunakan oleh abdi dalem Canthang Balung memiliki ciri - ciri yang berbeda dari keris-keris kebanyakan. Bilamana dilihat dari bentuknya keris yang digunakan oleh Canthang Balung dalam upacara Grebeg Mulud di Keraton Kasunanan Surakarta memiliki ciri - ciri bentuk sebagai berikut:

\section{Warangka}

Warangka adalah sarung bilah keris, yaitu bagian dari keris yang merupakan benda karya seni yang berfungsi sebagai pembungkus bilah keris yang memiliki nilai estetik (seni) dan nilai simbolis. Pada warangka keris Canthang Balung terdapat unsurunsur yang disebut ricikansebagaimana yang terdapat pada bilah keris. Dalam warangkaladrang terdapat ricikan atau ciri bentuk, antara lain: lenglengan, angkup, janggut, lata, ri cangkring, godhong, gandar, antup, ri pandan, pancatan, larapan godhongan, dan embat. Jenis keris ladrang yang digunakan pada keris Canthang Balung yakni keris ladrang jenis kasatriyan (kesatria). (Wawancara GPH Puger, 24 Maret 2007). 
Secara umum keris gaya Surakarta yang digunakan dalam upacara Grebeg Mulud di Keraton Kasunanan Surakarta hanya terdapat dua macam bentuk yang digunakan, yakni: warangka jenis ladrang, yang berbentuk seperti perahu panjang dan warangka jenis gayaman, yang konon asal mulanya merupakan stilasi dari bentuk buah gayam. Adapun jenis keris yang digunakan pada Canthang Balung yakni keris jenis ladrang.
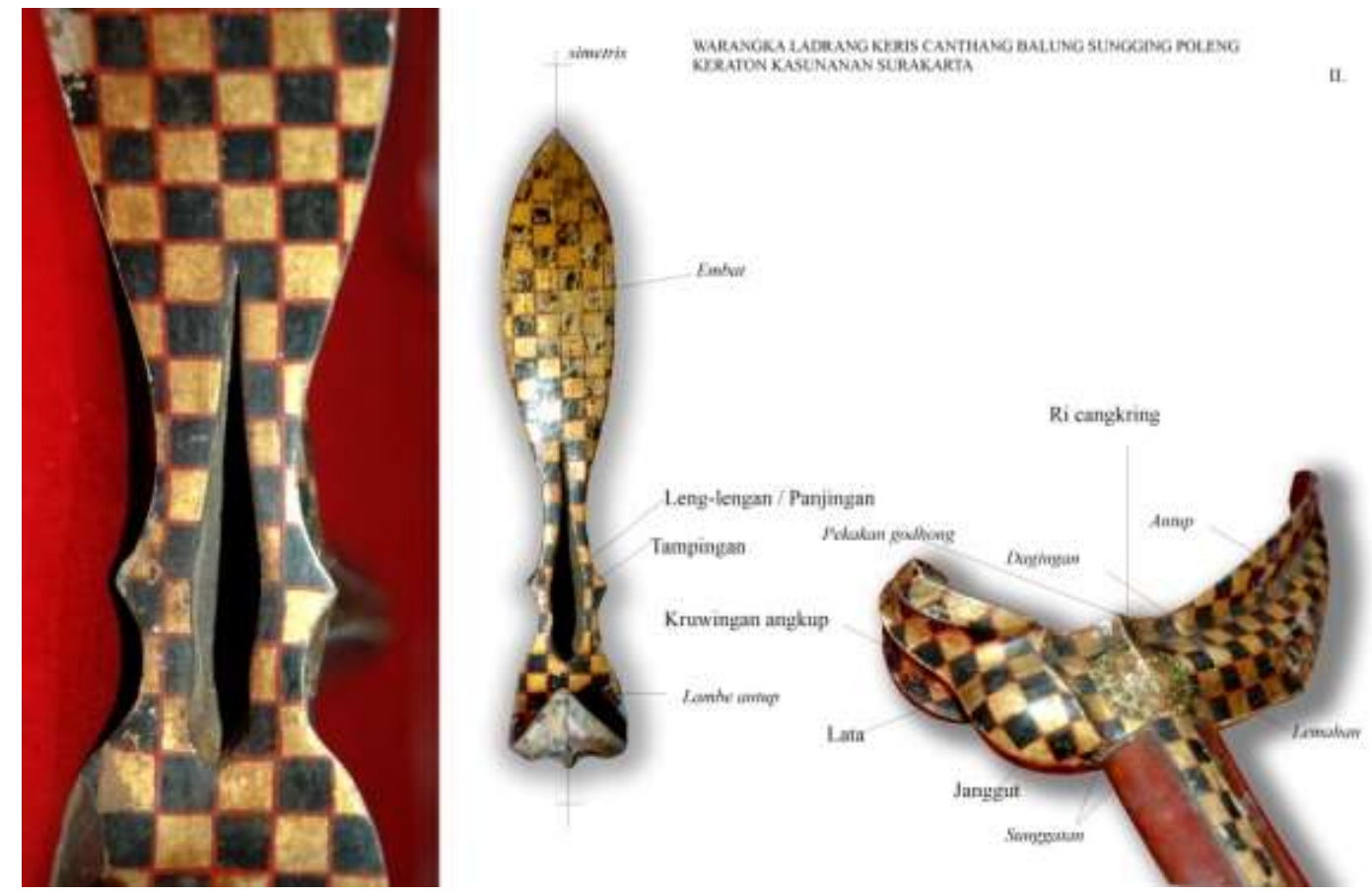

Gambar 2. Bentuk tampak atas dan perspektif warangka ladrangkasatriyan dengan motif sungging poleng yang digunakan oleh abdi dalemCanthang Balung di Keraton Kasunanan Surakarta.

(Foto: Jauhari, 2007)

Bentuk dasar warangkaladrang yang digunakan dalam upacara Grebeg Mulud umumnya menyerupai bentuk kapal kuno dengan susuh panjang melingkar ke atas seperti daun pandan (pada sebelah kanan dilihat dari depan) dan mengikat ujungnya yang biasa disebut sanggan atau godong. Sedangkan pada bagian kiri disebut angkup (daun pelindung) dan pada bagian tengah yang berfungsi untuk memasukkan bilah keris disebut cangkring.Pada kedua sisinya terdapat bentuk takik melengkung yang menyerupai sulur daun dan dinamakan lata. Di bagian bawah bawah bentuk godong atau sanggan terdapat sebuah tajuk yang agak runcing yang biasa disebut ri pandan dan pada bagian bawah angkup dengan bentuk seperti dagu biasa disebut janggut 
sedangkan terdapat jarak antara angkup dan sanggan yang disebut sebagai larapan. Secara visual dilihat dari bentuknya keris dengan warangkaladrang senantiasa dipakai dibelakang punggung atau sebagai wangkingan. Hal ini karena bentuknya yang lebih besar dan terlihat ringkih dan riwin (mudah rusak) sehingga dengan dikenakan dibelakang punggung, warangkaakan terlindungi oleh tubuh.

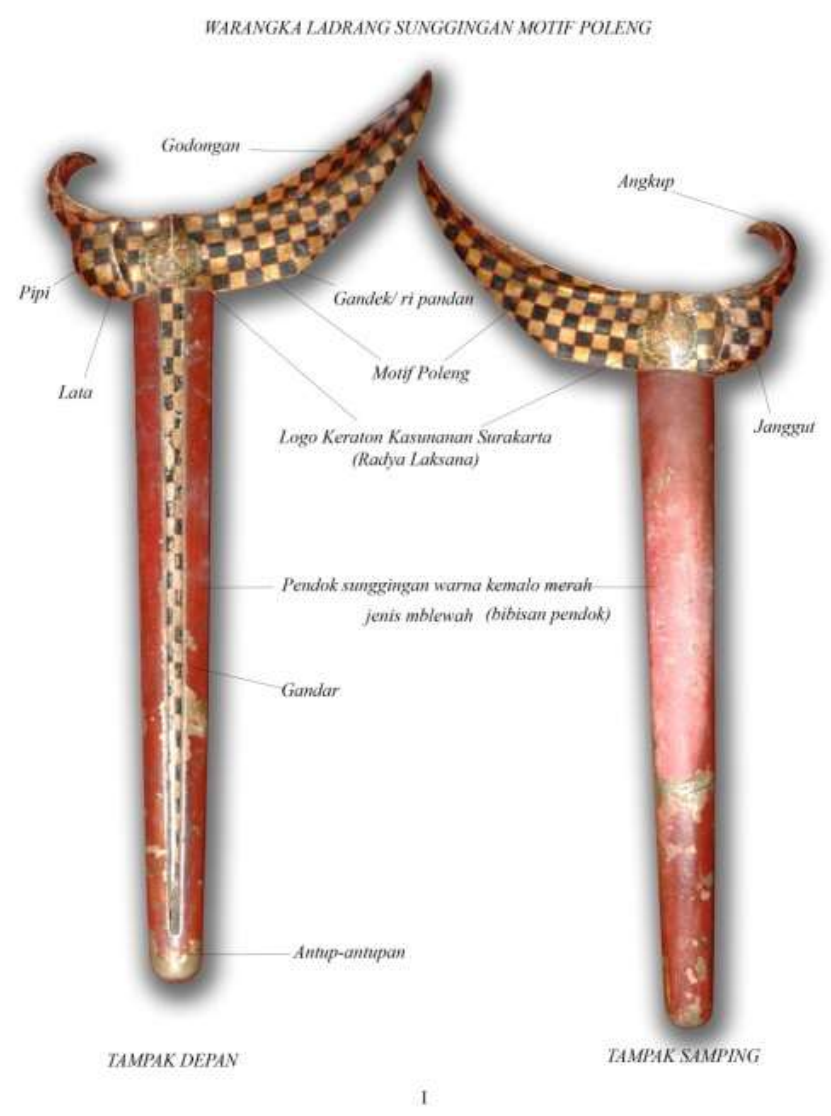

Gambar 3. Bentuk tampak depan dan belakang warangka ladrangkasatriyan dengan motif sungging poleng yang digunakan oleh abdi dalem Canthang Balung di Keraton Kasunanan Surakarta.

(Foto: Jauhari, 2007)

Warangka bila dilihat dari segi bentuknya dapat menambah nilai keindahan sebilah keris, bagaimanapun juga bilah keris tidak akan terlihat sempurna tanpa keberadaan warangka. Keberadaan warangka secara estetis memberikan nilai kekhasan pada keris itu sendiri, yakni sebuah kesatuan (unity) dengan bilah serta deder atau hulu (gagang) pada bilah. 
Ragam hias pada warangkakerisCanthang Balung menjadi ciri khas yang membedakan dengan keris-keris lainnya yang digunakan pada upacara Grebeg Mulud di Keraton Kasunanan Surakarta. Ragam hias pada warangkakeris cantang balung berbentuk motif poleng yang merupakan komposisi dari susunan motif geometris yang berbentuk bidang segi empat sama sisi beraturan berwarna hitam dan emas dengan garis tepi merah.

Pada gandarwarangka keris cantang balung berwarna warna merah hati yang menyatu dengan gandar. Ditengah titik antara gandar dan warangka terdapat logo Keraton Surakarta yang disebut Radya Laksana.

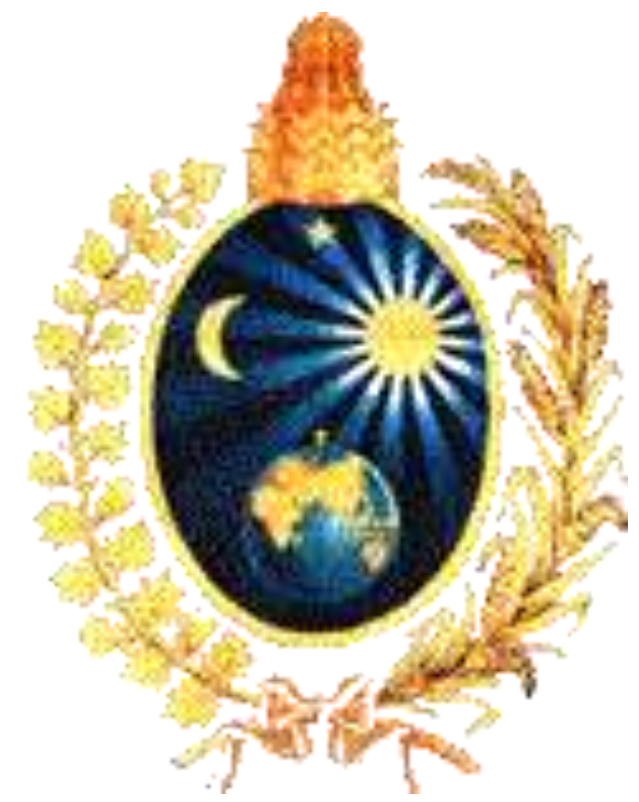

Gambar 4. Logo Keraton Kasunanan Surakarta : Radya Laksana

(Foto: Repro. Jauhari, 2007)

Pada warangka keris Canthang Balung yang digunakan di Keraton Kasunanan Surakarta selain dari segi ragam hiasnya yang berbeda, terdapat pula ciri lainnya yang membedakan dengan keris pada umumnya, yakni bilamana dilihat dari segi ukuran, jenis warangkaladrang yang digunakan Canthang Balung memiliki ukuran yang lebih besar dan lebih kecil serta keduannya tidak boleh dipisahkan satu sama lain sebagaimana pakem (aturan) terkait dengan kandungan makna simbolis serta filosofi dalam keraton. Begitu pula pada bagian lata dan ri cangring, yang terdapat ragam hias radya 
laksana ${ }^{1}$ yang mencirikan keris khusus milik Keraton Kasunanan Surakarta. (Wawancara GPH. Puger, 24 Maret 2007).

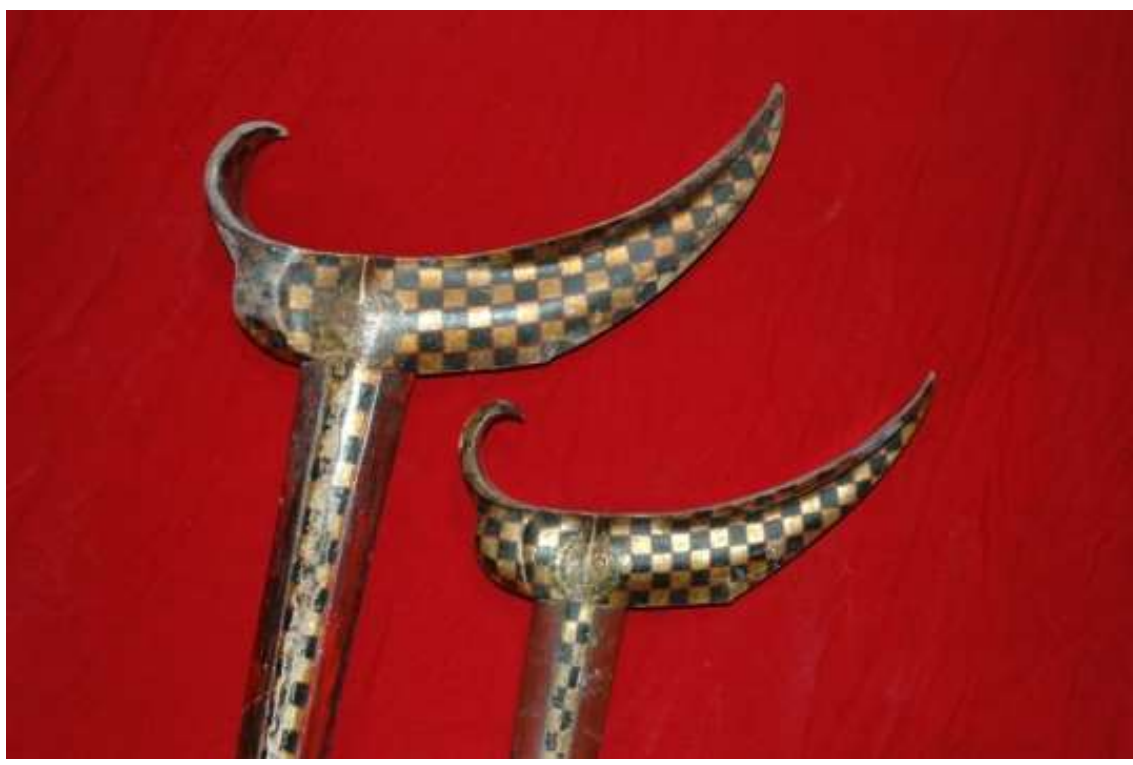

Gambar 5. Warangka jenis ladrangkasatriyan bermotif poleng pada keris Canthang Balung dengan dua ukuran yang berbeda di Keraton Kasunanan Surakarta

(Foto: Jauhari, 2007)

\section{Hulu atau deder}

Hulu atau deder pada keris Canthang Balung merupakan gagang yang berfungsi sebagai pegangan pada bilah keris. Deder dalam kerisCanthang Balung dalam upacara Grebeg Mulud di Keraton Kasunanan Surakarta diwujudkan dengan bentuk menyerupai bentuk figur wayang, yakni nyamba (mirip figur wayang Samba). Hulu dengan bentuk figur wayang Samba (nyamba) kebanyakan terbuat dari bahan kayu, kemudian diukir lalu disungging dengan bahan pewarna.Dalam hal ini, terdapat dua jenis hulu nyamba yang digunakan Canthang Balung, yakni satu bentuk nyamba dengan warna sungging, sementara bentuk lainnya polos (warna asli kayu).Puger dalam hal ini mengungkapkan bahwa, "warna asli (tanpa sungging) digunakan apabila garap (teknik ukir) pada hulu tersebut rapi serta cermat, sehingga tidak membutuhkan warna tambahan untuk menutupi kekurangan". (Wawancara dengan GPH. Puger, 31 Juni 2007).

\footnotetext{
${ }^{1}$ Radya laksana merupakan simbol Keraton Surakarta yang memiliki makna simbolis dan filosofis dalam kehidupan keraton pada khususnya dan masyarakat luas pada umumnya, Sumber: www.Javapalace.org, diakses 27 desember 2006.
} 
Adapun hal yang menarik dari hulu keris Canthang Balung (nyamba) ini yakni selain bentuknya yang merupakan figur tokoh wayang (Samba) juga terdapat cecekan. Cecekan secara khas merupakan ornamen yang berwujud ukiran halus berupa sebuah ukiran kecil yang diukirkan pada bagian depan hulu. Bentuk cecekan merupakan pakem yang tidak boleh dirubah orang semaunya.Pada zaman dahulu, cecekan menunjukkan bahwa pemakainnya memiliki kedudukan dan bukan orang biasa.Diperkirakan cecekan merupakan stilasi dari bentuk wajah janin yang melambangkan awal kehidupan atau daya hidup. (Rahardjo, 2003: 35)

Adapun nama bentuk ricikan yang terdapat pada hulu keris Canthang Balung (nyamba) yakni dhada, weteng, cecekan ngandhap, bungkul (gembung), pelangen, omah-omahan, panjingan, cethik (cekung), lingir(dering), gigir serta ukiran figur samba sebagai ciri yang membedakan dengan bentuk ukiran pada deder atau hulu lainnya.

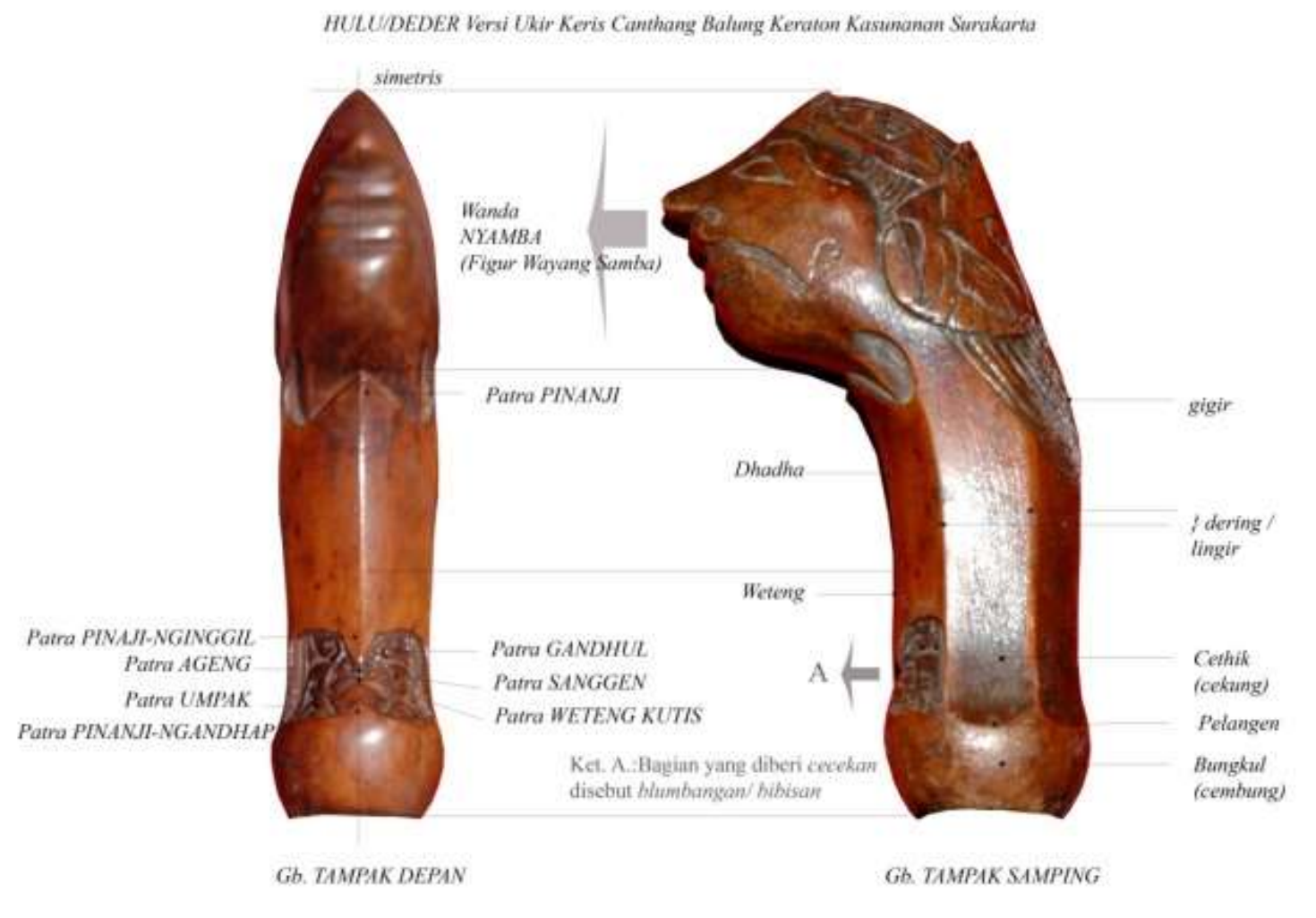

Gambar 6. Deder atau hulu dengan figur nyamba versi garap ukir pada keris Canthang Balung di Keraton Kasunanan Surakarta.

(Foto: Jauhari, 2007) 

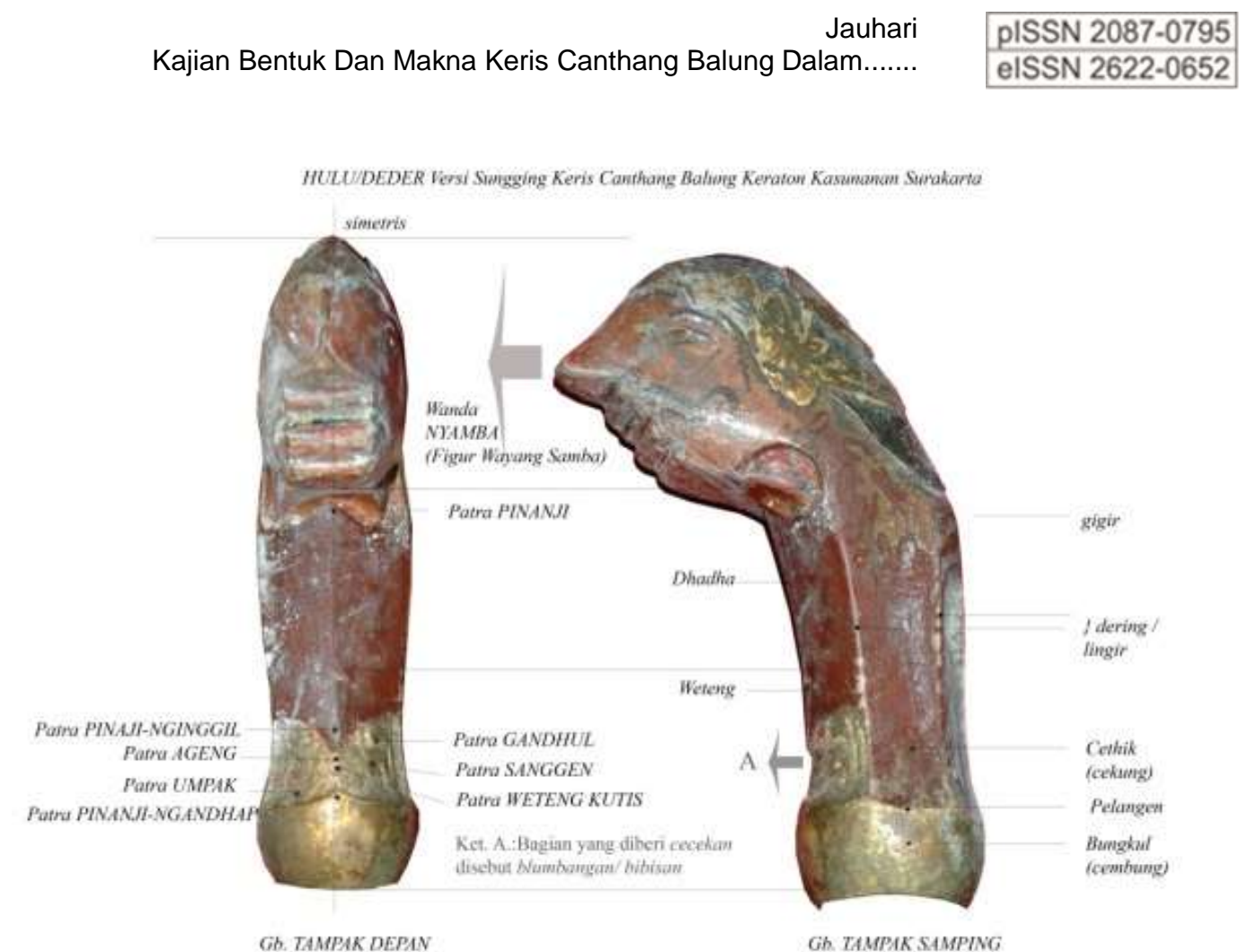

\section{Gambar 7. Deder atau hulu dengan figur nyamba versi garapsungging pada keris Canthang Balung di Keraton Kasunanan Surakarta.}

(Foto: Jauhari, 2007)

\section{Bilah (wilahan)}

Wilahan atau bilah keris adalah merupakan bagian inti dari sebuah keris. Dalam wilahan terdapat tiga bagian pokok yang menunjukkan sebuah ciri benda disebut sebagai keris, yaitu bagian pesi, ganja dan awak-awak, yang memiliki maksud dan makna tersendiri. Keberadaan wilahan pada kerisCanthang Balung di Keraton Kasunanan Surakarta ini berbentuk luk (berkelok) dan berbentuk lurus. Dalam wilahan terdapat hal yang paling mendasar dalam struktur bentuk wilahankeris, yaitu ricikan sebagaimana terdapat pada warangka. Dalam bilah keris (wilahan) pada keris Canthang Balung, ricikan keris terdiri dari antara lain: pesi, ganja, ricikan ganja, keadaan ganja, bentuk ganja, wilah, buntut (pucukan), gandhik, lambe gajah, jalen-sekar kacang, jenggot, pejetan, tikel alis, sogokan, janur, bungkul, bawang sabungkul, sraweyan, ri pandan, kanyut, thingil, greneng, randununut, ada-ada, gusen, kruwingan, sor-soran dan kudhup (pucuk).

Adapun bilah keris cantang balung di Keraton Kasunanan Surakarta memiliki bentuk dhapur yang berbeda satu dengan lainnya. Dhapur merupakan penamaan bentuk atau tipe keris. Dalam keris Canthang Balung di Keraton Kasunanan Surakarta terdapat dua 
macam keris yang masing masing memiliki nama dhapur tersendiri, yakni dhapurcarita mangkurat I untuk keris yang berkelok (luk) dan dhapurmundharang untuk keris lurus. Hal yang membedakan antara bentuk dhapur satu dengan lainnya yakni kelengkapan ricikan yang terdapat dalam keris tersebut. Kelengkapan ricikan keris pada wilahan tergantung pada kepiawaian seorang empu dalam membuatnya, disamping peranan penguasa (raja) dalam keraton yang sangat menentukan jumlah ricikan sesuai dengan yang dikehendaki. Adapun ricikan yang terdapat pada keris cantang balung yang berdhapurmundharang yakni sekar kacang pogog, lambe gajah, jalen, pejetan, tikel alis, araweyan, dan greneng, sedangkan ricikan yang terdapat pada keris Canthang Balung yang berdhapurcarita mangkurat I yakni sekar kacang pogog, jenggot, jalen, lambe gajah kalih, sogokan, tikel alis, sraweyan, greneng, gusen. (Wawancara dengan M.Ng. Suyanto, 26 Juni 2007)

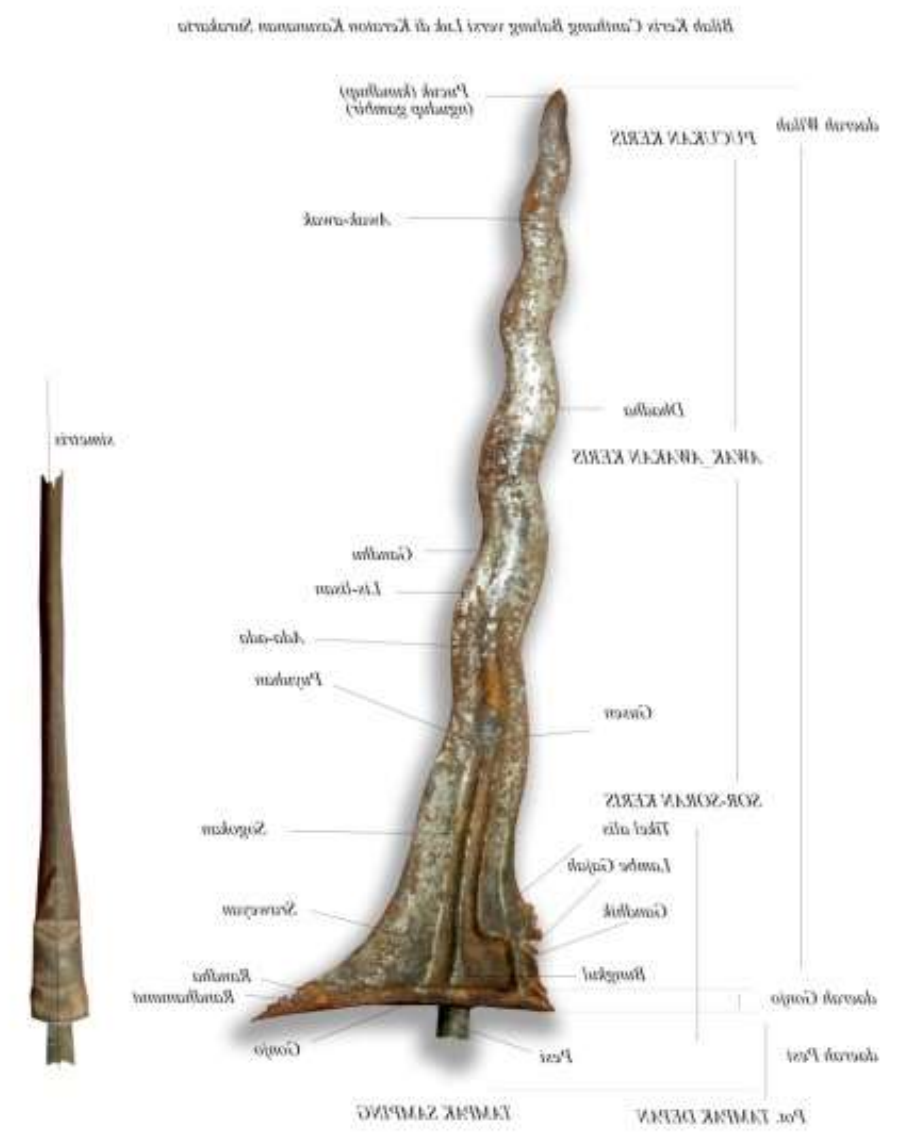

Gambar 8. Wilahan keris Canthang Balung versi luk (berkelok) di Keraton Kasunanan Surakarta.

(Foto: Jauhari, 2007) 
Bilah Keris Canthang Balung versi Lurus di Keraton Kasunanan Surakarta

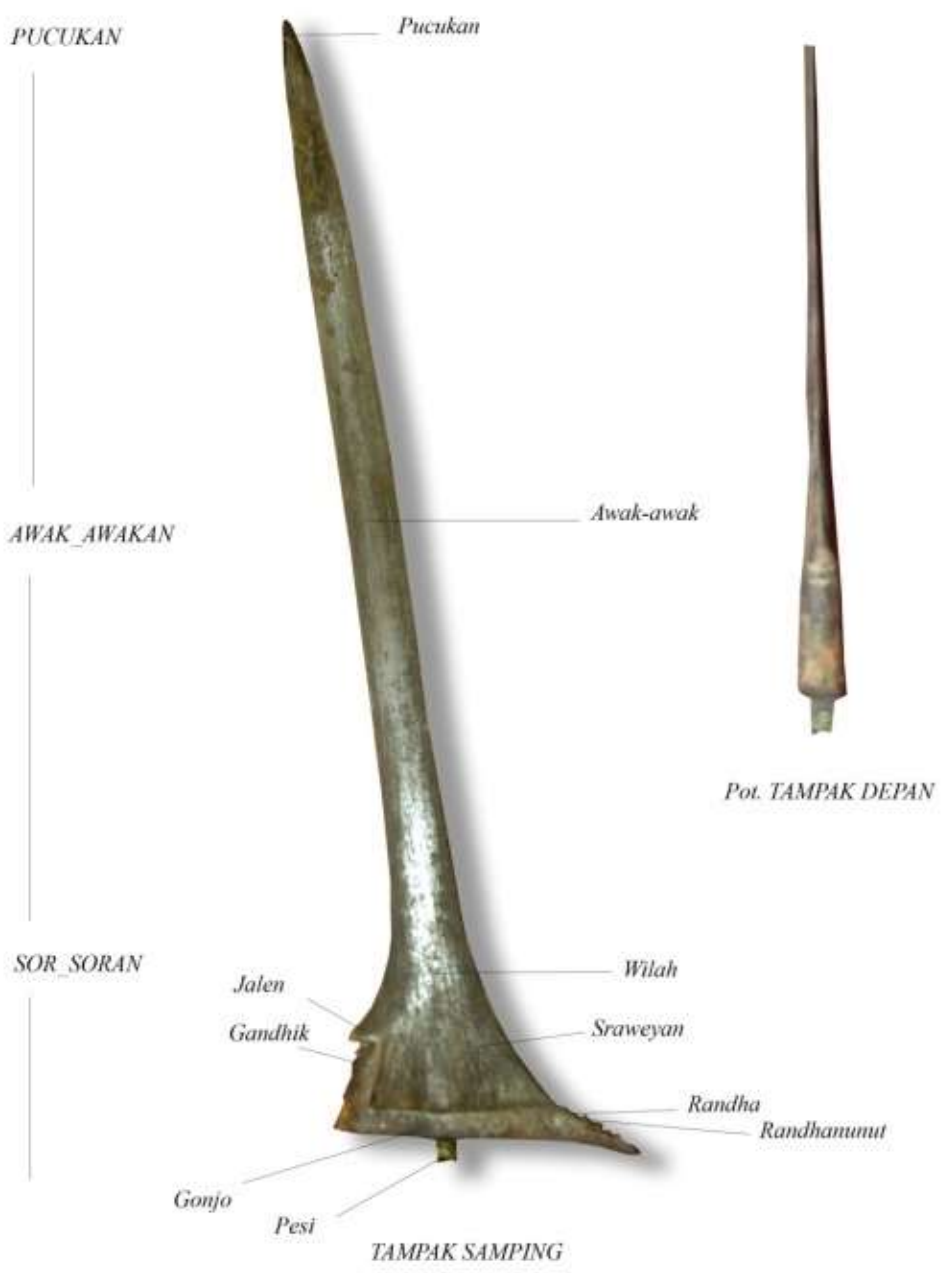

Gambar 9. Wilahan keris Canthang Balung versi lurus di Keraton Kasunanan Surakarta.

(Foto: Jauhari, 2007)

Dilihat dari bentuk bilah (wilahannya), bilah keris Canthang Balung yang berbentuk luk (berkelok) dan lurus yang digunakan di Keraton Kasunanan Surakarta terlihat kaidah-kaidah dalam seni rupa sebagaimana pada unsur visual (garis, warna, ruang, bentuk /bidang, tekstur, noktah), unsur komposisi (yang memperhatikan keseimbangan, pusat perhatian, pengulangan, kesatuan, keselarasan, irama, dan kontras), dan unsur teknik garap sebagaimana pula yang terdapat pada elemen-elemen keris lainnya.

Berdasarkan pada pengamatan peneliti, dilihat berdasar unsur visual perupaanya, pada bilah dapat kita lihat adanya garis tegas yang menghubungkan antara 
bidang ricikan satu dengan ricikan lainnya, warna yang merupakan unsur rupa alami yang memperkuat karakter dari bilah itu sendiri, ruang yang mengisi antar bidang di dalamnya, bentuk/bidang yang menjadikan bilah menjadi terlihat kokoh dan utuh, tekstur serta noktah yang melikupinya sebagai bagian dari elemen ragam hias yang muncul dengan sendirinya (pada pamor). Sedangkan pada unsur komposisi peneliti menginterpretasikan bahwa unsur ini merupakan elemen yang paling diperhatikan oleh empu pembuatnya pada zaman dahulu.Hal ini dapat kita lihat berdasarkan pada condong leleh yang merupakan pertautan dari keseimbangan bentuk, pusat perhatian, keselarasan, irama, kontras, serta teknik garap yang sangat sempurna, menjadikan sebuah karya yang monumental.Demikian pula hal ini yang terdapat pada elemenelemen keris lainya seperti pada warangka, deder atau hulu serta mendak.

\section{Mendak}

Mendak merupakan perlengkapan hiasan yang bentuknya seperti cincin melingkar yang menghubungkan antara deder dengan bilah pada gonjo (pesi bilah keris). Umumnya mendak terbuat dari tembaga, kuningan, perak ataupun emas dengan ornamen-ornamen. Mendak yang digunakan pada keris cantang balung dalam upacara Grebeg Mulud di Keraton Kasunanan Surakarta berbentuk sangat sederhana. Pada keris dengan bilah lukmendak yang digunakan tanpa ragam hias (polos), sedangkan pada bilah lurus mendak yang digunakan memiliki ragam hias berbentuk butiran pasir yang melikupi selubung mendak dengan motif geometris (segitiga) dengan warna keemasan (mentran pola B).

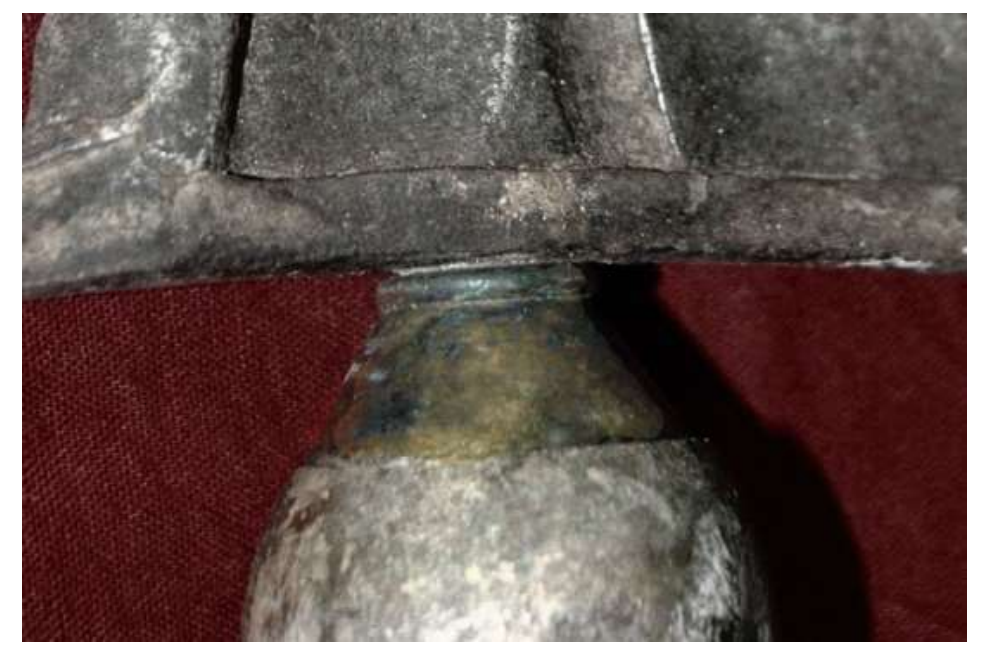

Gambar 10. Mendak versi garappolos pada keris Canthang Balung bentuk luk di Keraton Kasunanan Surakarta.

(Foto: Jauhari, 2007) 


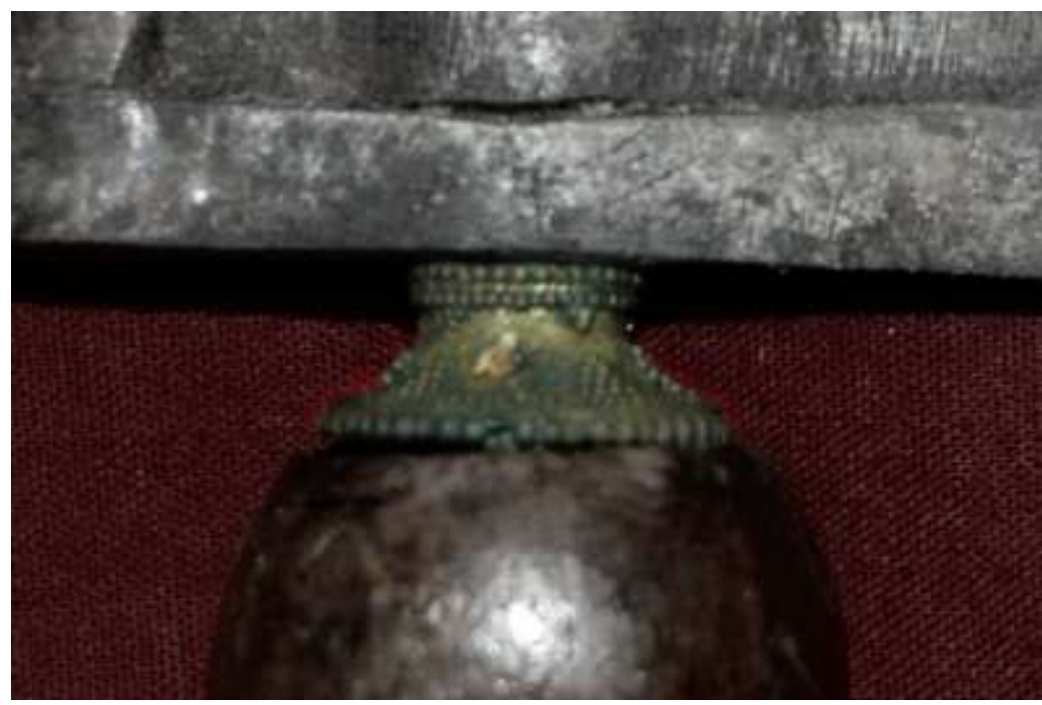

Gambar 11. Mendak versi garaphias berbentuk butiran pasir pada keris Canthang Balung bentuk lurus di Keraton Kasunanan Surakarta.

(Foto: Jauhari, 2007)

\section{Pamor}

Pamor mengandung dua pengertian. Yang pertama, pamor menunjuk pada gambaran tertentu berupa garis, lengkungan, lingkaran, noda, titik, atau belang-belang yang terlihat pada permukaan bilah keris, tombak maupun tosan aji lainnya. Sedangkan pengertian kedua, pamor adalah bahan pembuat pamor itu sendiri. (Raharjo, 2003: 35)

Dalam upacara Grebeg Mulud di Keraton Kasunanan Surakarta sebagaimana yang diutarakan oleh Puger bahwasanya pamor sudah tidak lagi menjadi hal yang sakral, hanya sebagian orang yang beranggapan bahwa pamor masih membawa sugesti yang berpengaruh bagi pemiliknya.Bilamana ditelaah dari segi garap, untuk mencapai bentuk pamor seperti yang diinginkan seorang empu melakukan beberapa kali pelipatan dan penempaan sehingga diperoleh pamor yang diinginkan.

Keris sebagaimana unsur-unsur dalam keris itu sendiri, merupakan sebuah karya yang memiliki nilai universal, yaitu dalam kosmologi Jawa disebut sebagai unsur makrokosmos dan mikrokosmos. Keris dengan pamor yang menyertainnya ketika sebagai sebuah karya estetis dipadukan dengan ragam hias yang melikupinya, maka keberadaan pamor sebagai bagian dari karya seni keris tidak berbicara terlalu tinggi, namun ketika memasuki era kerajaan terkait dengan legitimasi kekuasaan raja, maka muncul bahwasanya pamor memiliki karakterisasi nilai tersendiri, yaitu pada akhirnya pamor adalah sebuah medium bernuansa simbol sebagaimana pada unsur-unsur keris lainnya. (Wawancara dengan G.P.H. Puger, 24 Maret 2007) 
Adapun pamor dalam kerisCanthang Balung di Keraton Kasunanan Surakarta tidak dapat diketahui secara pasti karena keberadaan keris yang tidak terawat menjadikan pamortidak tampak. Namun dikatakan oleh Puger bahwasanya pamor pada keris Canthang Balung yakni pada bilah lurus berbentuk pamor mrambut sedangkan pada bilah luk berbentuk pamor wos wutah. (Wawancara dengan G.P.H. Puger, 8 Agustus 2007)

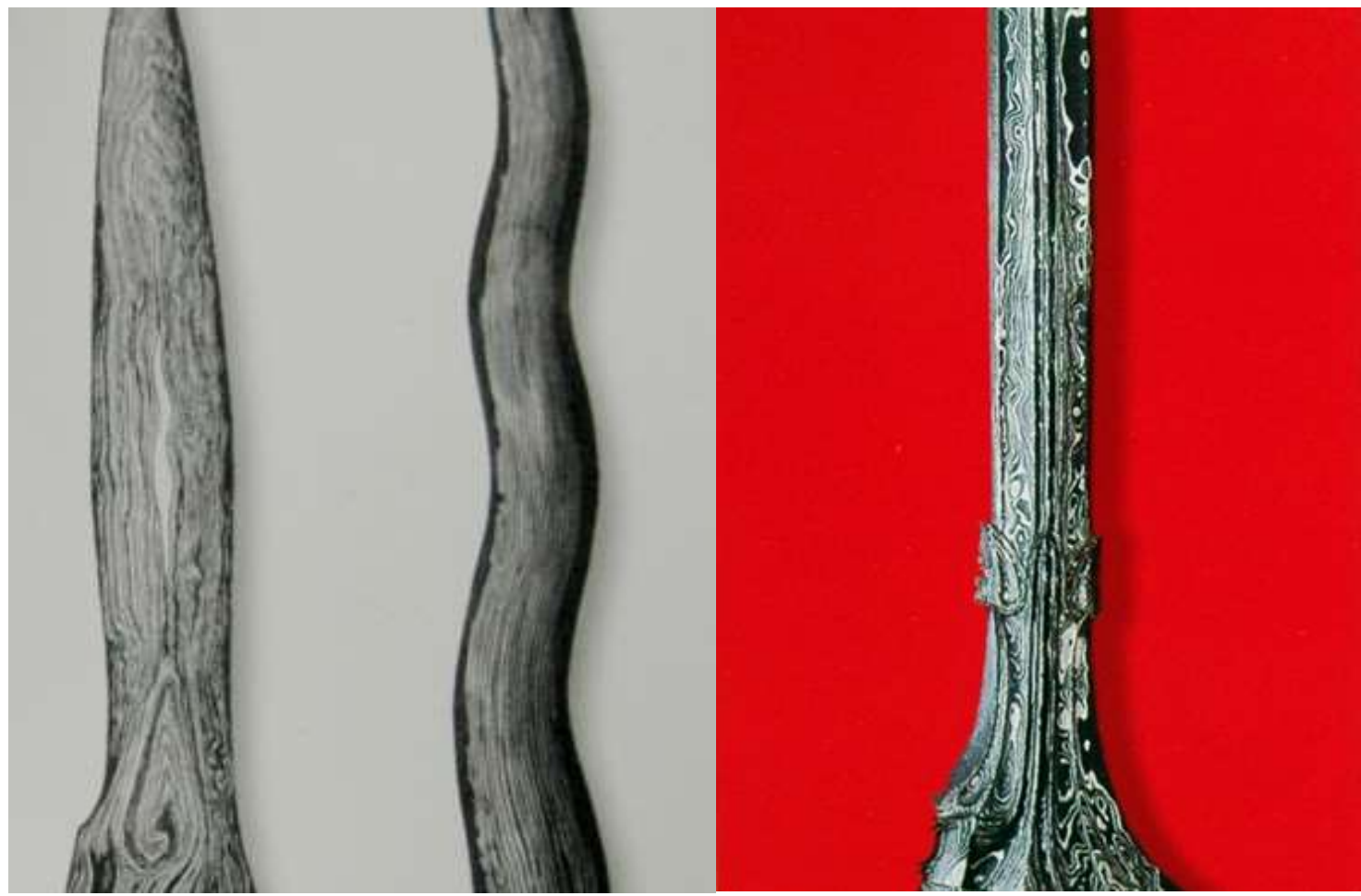

Gambar 12. Bentuk pamor mrambut atau adeg rambut (kiri) dan Bentuk pamor beras wutah atau wos wutah (kanan).

(Repro buku: Keris-Bambang H.)

Dari pengamatan peneliti bentuk keris Canthang Balung yang digunakan di Keraton Kasunanan Surakarta, secara umum memuat kaidah-kaidah estetik sebagaimana pada kaidah komposisi yang dikemukakan oleh Monroe Breadsley dalam The Liang Gie yang menjelaskan adanya tiga ciri yang menjadi sifat-sifat 'membuat baik (indah)' dari benda-benda estetis pada umumnya yakni adanya kesatuan (unity), kerumitan (complexity) dan kesungguhan (intensity). (The Liang Gie, 1976: 48) Ketiga ciri tersebut diatas kiranya tercermin sebagaimana pada unsur-unsur elemen yang terdapat pada keris Canthang Balung yakni sebagai berikut: 


\section{a. Kesatuan (Unity)}

Keris Canthang Balung merupakan suatu kesatuan yang utuh antara satu sama lain. Keutuhan serta kesatuan pada keris Canthang Balung ini terwujud melalui kesamaan unsur atau visual dari masing-masing bentuk elemental yang ditampilkan melalui unsur rupa yakni garis, warna, ruang, bentuk /bidang, tekstur, noktah. Unsur sebagaimana tersebut diatas antara lain tercapai melalui pola struktur yang terdapat pada elemen-elemen keris Canthang Balung seperti pada warangka, bilah, deder atau hulu serta mendak sebagai suatu kelengkapan yang menjadikannya kesatuan yang utuh.

Adapun pada warangka, unsur rupa terlihat melalui penempatan motif hias geometrisnya (poleng), baik sebagian maupun keseluruhan, yakni melalui perulangan raut, ukuran warna, maupun perulangan total dari keseluruhan unsur rupa tersebut dengan menempatkan pusat perhatian (center of interest) pada wilayah inti warangka, yakni pada area lata dan ri cangkring yang kemudian diberi simbol visual ragam hias radya laksana yang mencirikan Keraton Kasunanan Surakarta sebagai pusat jagad raya dan tatanan kosmos. Kesatuan pada warangka didukung oleh elemen lainnya yakni bilah dan deder yang sinergi.

Kesatuan dalam bentuk bilah kali ini terlihat melalui penampilan variasi visual dinamis dengan mengkhususkan bagian tertentu sebagai area inti. Sebagaimana dikemukakan oleh Basuki dan Agung, bahwasanya unsur estetika keris dapat dilihat melalui bentuk elemental bagian-bagian yang terdapat pada bilahnya. Selain pamor sebagai hiasan pada bilah keris, bentuk elemental seperti ricikan pada bagian sor-soran menjadi point of interest (inti) dari bentuk dhapur itu sendiri dalam memberikan bentuk yang terkesan utuh secara menyeluruh. Kesatuan serta keutuhan juga terwujud melalui penempatan bentuk-bentuk elemental lainnya yang saling berhubungan, yakni baik pada warangka maupun kelengkapan lainnya seperti mendak dan hulu atau deder. (Wawancara dengan Basuki Teguh Yuwono, 8 Juni 2007).

Pada hulu atau deder keris Canthang Balung juga merupakan suatu kesatuan yang utuh antara satu sama lain. Keutuhan serta kesatuan pada hulu keris Canthang Balung ini terwujud melalui bentuk elemental yang ditampilkan, yakni figur wayang berupa figur samba (nyamba) yang telah distilasi menjadi sedemikian rupa sehingga terlihat menyatu dengan bentuk pada elemen-elemen keris lainnya, seperti pada warangka, bilah serta kelengkapan lainnya yang berupa sesajidalam upacara Grebeg Mulud berupa untaian bunga mawar dan melati. Dalam hal ini termasuk di dalamnya 
juga pewarnaan yang digunakan yakni yang disungging ataupun yang tidak disungging yang saling bersinergi membentuk suatu kesatuan yang utuh.

\section{b. Kerumitan (Complexity)}

Warangka ladrang keris Canthang Balung memiliki kekayaan isi maupun unsurunsur yang saling berlawanan ataupun mengandung perbedaan-perbedaan yang halus. Keris Canthang Balung secara umum terlihat sangat tidak sederhana (complexity). Kedalaman bentuknya tertuang dalam proses garap yang rumit maupun konsep rupa pada unsur desainnya yang rumit. Hal ini terlihat melalui bentuk ricikan pada warangka maupun bilah serta elemen-elemen unsur lainnya yang saling melengkapi dan sinergi antara satu dengan yang lainnya. Pada warangka, bilah maupun deder ataupun kelengkapan lainnya, terlihat dengan jelas adanya detail penerapan bentuk pola pada ricikan yang rumit dari segi garap tekniknya maupun konsep yang dihadirkan oleh empu pembuatnya, disamping juga memperhatikan pula segi estetika pada elemenelemennya.

Penggunaan warna pada motif yang digunakan (poleng) juga tidak sedemikian rupa digunakan, termasuk pola pembentukan pamor, ricikan serta condong leleh pada bilah agar sinergi dengan deder (hulu), warangka serta kelengkapan lainnya. Hal ini ternyata dikarenakan terdapat tata aturan ataupun kaidah-kaidah (pakem) yang harus dilaksanakan dalam implementasinya, terkait pula dengan nilai-nilai simbolis serta filosofi yang hendak disampaikan. Hal ini membuktikan bahwa keris Canthang Balungbeserta kelengkapannya merupakan salah satu artefak budaya yang memiliki nilai kerumitan tinggi disamping nilai-nilai lainnya yang terdapat di dalamnya.

\section{c. Kesungguhan (Intensity)}

Kesungguhan garap (intensity) pada keris Canthang Balung terlihat melalui kwalitas rupa yang menonjol. Dilihat dari rupa ragam hiasnya, penggunaan motif poleng dengan unsur geometris yang berulang dengan pewarnaan teknik sungging dengan warna yang sinergi atau warna yang saling mendukung satu sama lain membawa kepada sebuah sajian yang utuh pada nuansa mistis. Hal di dukung oleh kelengkapan sesaji berupa untaian bunga mawar, melati dan kantil menambah karakter mistis disamping dari segi garap-nya yang sangat sempurna (perfect). Warna warangka merah hati dan emas memberi kesan garang, disamping pula merupakan simbolisasi dari bangsawan atau sesuatu yang dianggap 'agung' (memiliki kedudukan yang tinggi). 


\section{B. Makna Simbolis Bentuk Keris Canthang Balung}

Pandangan tentang gunung sebagai sesuatu yang keramat sampai saat ini masih kental dalam kosmologi hidup orang Jawa. Gunung menurut kepercayaan Jawa merupakan jembatan dunia atas dengan dunia bawah, oleh karenanya banyak tempat pemujaan yang didirikan di tempat yang tinggi (dataran tinggi atau pegunungan). Adapun keterkaitan bentuk dan makna keris dengan konsepsi tentang gunung itu sendiri memiliki makna yang sangat erat dan saling terkait satu sama lain. Gunung dalam perkembangan sejarah direfleksikan dengan bentuk punden berundak-undak serta keberadaan menhir sebagai tempat sarana ritual tempat bersemayamnya ruh nenek moyang (Zaman Megalitikum), kemudian perkembangan Hindu, Budha menjadi bentuk candi yang mengerucut keatas sebagaimana bentuk gunung dan dianggap sebagai tempat bersemayamnya para dewa-dewa penguasa kosmos.

Demikian pula yang terjadi pada bentuk bilah keris. Fenomena keberadaan keris sebagai benda yang dianggap sinengker (memiliki kekuatan gaib), dalam hal ini keris Canthang Balung dalam upacara Grebeg Mulud (gunungan) yang diselenggarakan di Keraton Kasunanan Surakarta merupakan bukti terjadinya perkembangan budaya (sinkretisme) terhadap masuknya ajaran baru (Islam). Kesemuannya tentunya tidak terlepas dari nilai sejarah yang mengawalinya.

Menhir, merupakan salah satu peninggalan budaya simbolisasi dari tempat bersemayamnya ruh nenek moyang, pada keris divisualisasikan melalui bentuk hulu atau deder.

Dilihat dari sejarah perkembangan budaya dalam bentuk artefak serta mentifak tentunya tidaklah sesederhana sebagaimana yang kita bayangkan. Terdapat banyak dekade kurun waktu yang lama sampai pada akhirnya terdapat bentuk keris Canthang Balung sebagaimana yang kita lihat sekarang ini. Adapun hal yang sangat berperan terhadap perubahan bentuk keris Canthang Balung yakni masa setelah masuknya ajaran Hindu serta Budha yaitu masa peralihan Islam dengan ajarannya yang tegas tentang keesaan Tuhan merupakan langkah besar ke arah kemajuan kerohanian.

Iman kepada Tuhan, pencipta alam yang bersifat Ar Rahman dan Hakim dalam hal ini berarti merupakan koreksi besar atas kepercayaan kepada dewa-dewa dan alam siluman. Namun pengislaman rakyat tidak sepenuhnya berhasil penuh. Sinkretisme budayapun akhirnya terjadi sampai sekarang sebagaimana perkembanganperkembangan agama-agama sebelumnya untuk kemudian menjadi budaya yang 
dianggap memiliki nilai dan makna yang adiluhung dengan pola tatanan sedemikian rupa.

Adapun makna keberadaan upacara seperti sekaten dengan Grebeg Mulud (gunungan) serta keberadaan Canthang Balung dengan atribut keris yang menyertainnya sebagai bagian dari budaya tradisi merupakan wujud dari sinkretisme yang kemudian berkembang menjadi tradisi budaya pada perkembangan kerajaan setelah masuknya Islam. Keraton Kasunanan Surakarta merupakan salah satu pewaris kerajaan Mataram Islam yang sampai saat ini keberadaannya masih eksis.

Keris Canthang Balung dalam Grebeg Mulud merupakan salah satu artefak budaya dengan bentuk yang unik yang mengadopsi beberapa muatan ajaran-ajaran agama yang telah lama berkembang di Indonesia. Yakni tentang kesuburan yang diwujudkan dengan simbolisasi lingga dan yoni pada warangka keris dengan kelengkapan bilah kerisnya atau pula pada bilah keris yang didalamnya terdapat peksi dengan gonjo. Selain itu juga simbolisasi dari perjalanan hidup (sangkan paraning dumadi) yang disimbolkan dengan hulu atau deder sebagai gambaran tentang roh (bentuknya merupakan stilasi perkembangan dari bentuk menhir²) dan bentuk warangka ladrang yang menyerupai kapal sebagai perahu roh. Disamping itu bentuk bilah keris yang berupa luk (berkelok) sebagai simbolisasi dari sifat manusia yang diibaratkan naga nglangi yakni senantiasa mencari kesempurnaan hidup sedangkan bilah yang berbentuk lurus yang diibaratkan sebagai naga tapa merupakan simbolisasi dari tahapan menepi atau menep dalam konteks lahir dan batin manusia menuju kemanunggalan terhadap gusti(Tuhan)nya dengan melalui beberapa gambaran tingkatan-tingkatan sebagaimana terdapat pula pada gunungan. Kesemuannya menuju pada pada konsepsi kosmologi Jawa yakni manunggaling kawula Gusti. Sebagaimana dikemukakan oleh Jakob Sumardja dalam bukunya estetika paradoks bahwasanya keris merupakan medium vertikal sebagaimana pada gunungan, pohon hayat, pucuk rebung, tumpal, candi dan stupa. Keris dianggap keramat karena merupakan karomah, medium sakral. Sehingga strukturnyapun dibagi menjadi tiga bagian tingkatan-tingkatan sebagaimana pada candi ataupun gunungan, yakni bagian bawah, tengah dan pucuk. (Sumardja, 2006: 213).

Upacara Grebeg Mulud Keraton Kasunanan Surakarta merupakan upacara sedekah yang diselenggarakan sebagai penutup berakhirnya sekaten dan ditandai dengan ritual sedekah gunungan. Prosesi ritual kirab Grebeg Mulud yang umumnya dikenal dengan sebutan gunungan. Sebagaimana yang telah dikemukakan diatas,

\footnotetext{
${ }^{2}$ Menhir merupakan hasil budaya pada zaman megalitikum yang berorientasi pada pemujaan roh nenek moyang.
} 
gunungan merupakan selamatan Hajad Dalem Sultan (raja) yang berwujud 'nasi tumpeng' lengkap dengan lauk pauknya, serta hasil alam yang diwujudkan dengan ujud gunung dan seringkali disebut sebagai gunungan. Gunungan sebagai simbol pusaka merupakan simbolisasi dari alam semesta beserta isinya. Gunungan juga diyakini oleh sebagian besar masyarakat lingkungan keraton sebagai simbol keseimbangan hidup di dunia. Gunungan pada umumnya menggambarkan alam semesta beserta isinya serta melambangkan kesuburan, kemakmuran dan kehidupan. Gunungan dalam pewayangan dengan kelir berwarna putih dapat dimaksudkan sebagai simbol kehidupan manusia di dunia yang sebenarnya seperti sebuah panggung sandiwara. Gunungan pada dasarnya mencerminkan hidup manusia ketika didunia, yakni mulai dari manusia itu lahir, tumbuh (proses pendewasaan), sampai pada akhirnya meninggal dunia atau dalam ungkapan filosofi Jawa disebut sangkan paraning dumadi (kembali ke asal) serta manunggaling kawula Gustiyakni bahwasanya segala yang ada dia alam semesta ini merupakan aspek lahir dari segala yang hakikat yaitu Tuhan.

Keberadaan gunungan sebagai bentuk sajian dan keris Canthang Balung di Keraton Surakarta sebagaimana tercermin dalam ritual Grebeg Mulud menggambarkan bersatunya jagad cilik dan jagad gedhe untuk mendukung terwujudnya jagad yang ideal. Hal ini juga disimbolkan sebagaimana keberadaan keris cantang balung ke dalam bentuk yang serba dua (konsepsi dualisme). Keberadaan keris dan gunungan menyimbolkan berpadunya mikrokosmos, makrokosmos dan metakosmos. Keyakinan ini terwujud dalam kebatinan Jawa yakni konsepsi manunggaling kawula Gusti dan sangkan paraning dumadi. Konsep tersebut memberikan pengertian upaya kemanunggalan atau mendekatkan diri kepada Tuhan serta pada beberapa hal menyangkut asal dan tujuan hidup manusia di dunia.

Sesuai dengan pendapat yang dikemukakan oleh Prof. Dr. J. van Baal dalam buku beliau Symbols for Communication (1971) dalam Koentjaraningrat dikemukakan bahwa sajian merupakan pemberian atau persembahan kepada dewa yang digemari oleh para dewa dan roh tetapi juga mengandung lambang-lambang guna berkomunikasi dengan dewa itu. Kain bangun tulak yang seperti motif poleng dalam warangka keris Canthang Balung merupakan kegemaran Dewi Durga. Sebagaimana hubungan ceritera antara Dewi Durga dan Ciwa merupakan figur dewa dan dewi yang dipuja dalam kosmologi masyarakat Hindu. Kesemuannya pada hakekatnya merupakan lambang agar tercapai keseimbangan atas daya-daya transenden serta imanen. (Koentjaraningrat, 1985: 124). 


\section{SIMPULAN}

Keberadaan keris canthang balung dalam upacara Grebeg Mulud di Keraton Kasunanan Surakarta memiliki fungsi sebagai kelengkapan atau ubarampe upacara adat yang menyertai keberadaan canthang balung sebagai media illuminasi (perantara) atau penghubung antara alam nyata dan gaib. Secara umum keris canthang balung merupakan bentuk peninggalan budaya yang memiliki nilai estetis. Hal ini karena pada bentuknya terdapat ciri yang mendasari sebagimana dikemukakan oleh Monroe Beardsley yakni adanya kesatuan (unity), kerumitan (complexity) serta kesungguhan (intensity) di dalam wujudnya.

Secara simbolis keris canthang balung memiliki kaitan yang sangat erat dengan keberadaan gunungan dalam upacara Grebeg Mulud di Keraton Kasunanan Surakarta. Makna simbolis keberadaan keris canthang balung dengan gunungan termaktub sebagaimana dalam konsep triloka atau tribuana dan konsep mandala. Adapun makna keris canthang balung dalam pembahasan terhadap konsep triloka atau tribuana lebih mengarah pada tataran konteks hubungan transenden, sedangkan pada konsep mandala lebih kepada konteks hubungan imanen. Disamping tersebut diatas, makna simbolis yang terdapat keris canthang balung juga mengacu pada unsur simbolis pewarnaannya. Bilamana dilihat dari aspek pewarnaannya, keris cantang balung sebagian besar dipenuhi dengan warna-warna.

Warna pilihan yang diterapkan pada keris canthang balung merupakan warna yang sarat akan muatan simbolis yang berdasar pada sistem kepercayaan yakni kejawen. Warna tersebut antara lain: warna coklat yang menurut falsafah Jawa merupakan simbol dari kebahagiaan dan kesucian. Selain itu juga simbol dari rejeki, keberuntungan, dan keberanian. Warna hitam merupakan simbol dari kesucian, keluhuran, arif, bijaksana, keteguhan hati. Warna merah dalam budaya Jawa merupakan simbol kasepuhan atau simbol kedewasaan dan kemenepan. Jiwa kasepuhan atau kedewasaan merupakan simbolisasi dari terciptannya kemenepan sejati yang membawa ketentraman, keharmonisan antara alam beserta isinya dalam konteks makrokosmos, mikrokosmos serta metakosmos. Warna emas merupakan simbol dari kebesaran, keagungan dan juga kemegahan, serta warna hijau yang merupakan simbol kesuburan. Hal ini terwujud pada ragam hias yang digunakan pada keris canthang balung, yakni dominasi motif poleng.

Ragam hias motif poleng terdapat pada keris canthang balung dengan struktur pola empat (konsep 'papat keblat lima pancer') dianggap oleh masyarakat di lingkungan Keraton Kasunanan Surakarta sebagai tolak bala, dapat menstabilkan 
ketidakseimbangan antara kehidupan makrokosmos, mikrokosmos dan metakosmos, sehingga hal-hal yang dirasa tidak mengenakkan (musibah) dapat dihilangkan. Falsafah memayu hayuning buwana (menyelamatkan dan melestarikan dunia) merupakan cerminan sikap batin manusia dalam usahannya menyelaraskan dan menyeimbangkan alam makrokosmos, mikrokosmos dan metakosmos melalui upacara-upacara adat Jawa.

Keris canthang balung yang diartikan dan diyakini dalam upacara Grebeg Mulud di Keraton Kasunanan Surakarta merupakan sebuah pengejawantahan simbol perjalanan hidup manusia dan harapan yang memuat falsafah hidup manusia, sekaligus merupakan penggambaran perwujudan kehidupan manusia kearah pencapaian kesempurnaan hidup dalam hubungannya antara makhluk ciptaanya (kawula) dan Tuhannya (Gusti) serta dengan lingkungan sekitarnya (alam semesta dan manusia lainnya). Keberadaan keris canthang balung dalam upacara Grebeg Mulud di Keraton Kasunanan Surakarta menjadi salah satu sarana, yang keberadaannya memiliki peranan penting dalam kosmogoni Jawa khususnya dalam upacara adat keagamaan di lingkungan Keraton Kasunanan Surakarta.

Upacara Grebeg Mulud yang merupakan salah satu upacara adat keagamaan dalam rangka dakwah dan syiar agama Islam yang tidak dapat terlepas dari peranan keris khususnya keris canthang balung, sebagaimana dalam konsepsi falsafah Jawa manunggaling kawula-Gusti serta sangkan paraning dumadi.

Dengan terungkapnya permasalahan yang menyangkut tentang keberadaan keris canthang balung dalam upacara Grebeg Mulud di Keraton Kasunanan Surakarta diharapkan penulisan skripsi ini dapat menjadi bahan referensi tentang keris. Keris merupakan salah satu benda budaya yang seyogyanya dilestarikan karena mengandung muatan nilai-nilai adi luhung yang diwujudkan secara simbolis.

\section{DAFTAR PUSTAKA}

Bambang Harsrinuksmo, Ensiklopedi Keris, Jakarta: Gramedia Pustaka Utama, 2004. Budiono Herusatoto, Simbolisme dalam Budaya Jawa, Yogyakarta: PT. Hanindita, 1984. Haryono Harjoguritno, Keris Jawa: Antara Mistik dan Nalar, Jakarta: Indonesia Kebanggaanku, 2005. 
H.B. Sutopo, Metodologi Penelitian Kualitatif, Surakarta : UNS Press, 2006.

Jakob Sumardjo, Estetika Paradoks, Bandung: Sunan Ambu Press, 2006.

Jauhari, Skripsi, Kajian Keris Canthang Balung dalam Upacara Grebeg Mulud di Keraton Kasunanan Surakarta, ISI Surakarta, 2008

Ki Hudoyo Doyodipuro, Occ, Keris, Daya Magic-Manfaat-Tuah-Misteri, Semarang: Dahara Prize, 2001.

Koentjaraningrat, Kebudayaan Jawa, Jakarta: Balai Pustaka, 1994.

Koentjaraningrat, Ritus Peralihan di Indonesia, Jakarta: Balai Pustaka, 1985.

Lexy J. Moleong, Metodologi Penelitian Kualitatif, Bandung: PT. Remaja Rosdakarya, 1993.

Liang Gie, The, Garis Besar Estetika, Yogyakarta: Supersukses, 1983.

Peursen, van C.A, Strategi Kebudayaan, Yogyakarta: Kanisius, 1988.

Mari S.Condronegoro, Busana Adat Kraton Yogyakarta - Makna, Fungsi, Berbagai Upacara, Yogyakarta: Yayasan Pustaka Nusatama, 1995.

Nyoman Kutha Ratna, Estetika Sastra dan Budaya, Yogyakarta: Pustaka Pelajar, 2007.

Sujamto, Refleksi Budaya Jawa, Semarang: Dahara Prize, 1992.

Suhartono Rahardjo, Ragam Hulu Keris Sejak Zaman Kerajaan, Yogyakarta: Kreasi Wacana, 2003.

\section{Daftar Narasumber}

Basuki Teguh Yuwono, S.Sn., Surakarta, Staf Pengajar/ Dosen ISI Surakarta dan Empu muda keris di Surakarta.

G.P.H. Puger, B.A., Surakarta, Putra Paku Buwana XII, Pengageng Sasana Pustaka dan Museum Karaton Kasunanan Surakarta.

K.R.A.T. Wiranto Diningrat, Surakarta, Pangarsa Prajurit Karaton Kasunanan Surakarta.

K.R.T. Subandi, Surakarta, Empu keris di Surakarta dan Staf Studio keris ISI Surakarta.

Mas Lurah Rekso Duworo, Surakarta, abdi dalem canthang balung di Keraton Kasunanan Surakarta.

M.Ng. Suyanto, Surakarta, Empu keris di Surakarta dan Staf Studio keris ISI Surakarta. M.Ng. Daliman, Surakarta, Empu Keris di Surakarta dan Staf Studio keris ISI 